\title{
ペイント法を用いた有機薄膜太陽電池の作製と評価*
}

\author{
石原 啓史 $* 1$. 小嶋 憲三*1 · 水谷 照吉 $* 1 \cdot$ 落合 $\quad$ 鎮康 $* 1$
}

\section{Fabrication and Performance of Organic Thin Film Solar Cells Using the Brush Painting Method}

\author{
Hirohumi ISHIHARA*1, Kenzo KOJIMA*1, Teruyoshi MIZUTANI*1 and Shizuyasu OCHIAI*1 \\ ${ }^{* 1}$ Dept. of Electrical Eng, Aichi Inst. of Tech, 1247 Yakusa, Toyota 470-0392, JAPAN
}

(Received October 30, 2009, Accepted March 5, 2010)

\begin{abstract}
As organic solar thin films fabricated by an active layer of organic materials are economical, lightweight, and flexible, as well as facilitating processing, organic solar cells have attracted considerable attention within the past few decades as a clean energy source. With this in mind, there have been global investigations and studies of the power conversion efficiency (PCE) within organic solar cells. In organic thin-film solar cells, the effect of the performance is not only dependent on an adopted active material but also the molecular orientation on the electrode. Using the mixed solution of Poly (3-hexylthiophene) and PCBM, both dissolved by solvent, an organic thin film is fabricated using the paint method (The conceptual diagram of the paint method is shown in Fig. 1) The form of the thin film was evaluated, an organic thin-film solar cell using the paint method for the active layer was made, and its performance was evaluated and examined.

Using the mixed solution of Poly (3-hexylthiophene) and PCBM, both dissolved by solvent, an organic thin film is fabricated using the paint method (The conceptual diagram of the paint method is shown in Fig. 1) The morphology of the thin film was evaluated using an AFM image, UV/vis spectra, and so forth. Based on these data, an organic thin-film solar cell that used the paint method for the active layer was fabricated, and the performance was evaluated and examined. For the organic thin film solar cell fabricated using the brush painting method, the open-circuit voltage (Voc) is $0.41 \mathrm{~V}$, the short circuit current density (Jsc) is $2.07 \mathrm{~mA} / \mathrm{cm}^{2}$, and the fill factor is 0.34 . The efficiency $\eta$ of PCE becomes $0.29 \%$.
\end{abstract}

\section{1. はじめに}

近年, 低価格, 軽量, フレキシブル，易作製プロセス，大 面積化可能などの利点を有する有機薄膜太陽電池の研究, 開 発が盛んになされている. 有機薄膜太陽電池では, 使用材料 だけでなく，その分子配向が性能に与える影響が大きい1-5).

本研究では有機溶媒に可溶なポリマー材料である Poly (3hexylthiophene-2,5-diyl)（以下 P3HT と略す）とフラーレ ン誘導体の [6,6]-Phenyl C61 butyric acid methyl ester（以 下 PCBM と略す）を用いてペイント法6)（ペイント法の概

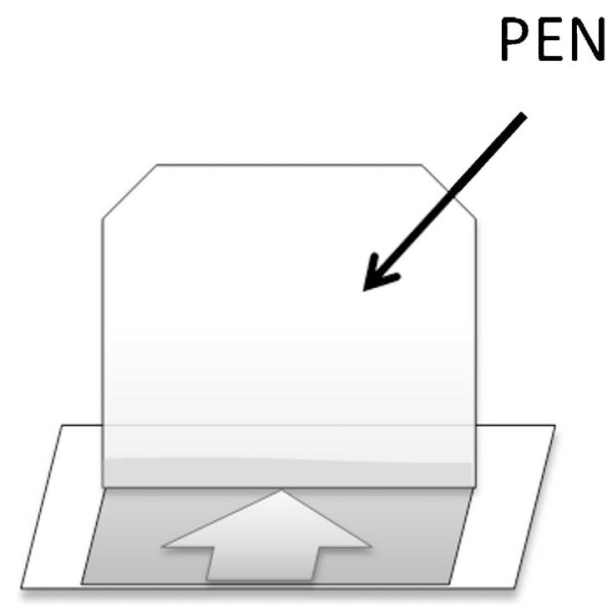

Fig. 1 The conceptual diagram of the painting method.

* 平成 21 年 11 月 4 日 第50回真空に関する連合講演会で発表

*1 愛知工業大学（恧470-0392 愛知県豊田市八草町八千草1247)
念図を Fig. 1 に示す.）により有機薄膜を作製し，薄膜の形 態評価をするとともに, 活性層にペイント法を用いた有機薄 膜太陽電池を作製し，その性能を評価・検討した。

\section{2. 実験方法}

Indium thin oxide（以下 ITO と略す）透明電極上にバッ ファ層として Poly (3,4-ethylenedioxythiophene) / poly (styrene sulfonate）（以下 PEDOT/PSS と略す）をスピンコー ト法で製膜し， $130^{\circ} \mathrm{C}$ で加熱乾燥した。次にクロロホルムと クロロベンゼンを体積比 $1: 1$ で混ぜた混合溶液にPoly $(3-$ hexylthiophene-2,5-diyl) [P3HT] を0.1 wt\%, フラーレン 誘導体の $[6,6]-$ Phenyl $\mathrm{C}_{61}$ butyric acid methyl ester $\{\mathrm{PCBM}\}$ を 0.08 wt \% 溶かし, Polyethylenenapfthalate (PEN) の板で, 滴下した溶液を一方向へ塗り広げるぺイン ト法により PEDOT/PSS 上に活性層を製膜した。ここまで はすべて大気中で行った．これにアルミニウム $[\mathrm{Al}]$ 電極 を真空蒸着することで有機薄膜太陽電池を作製した. Fig. 2

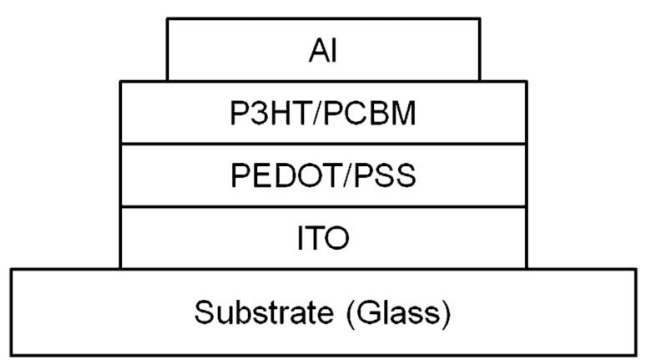

Fig. 2 The cross sectional structures of the organic thin film solar cell. 


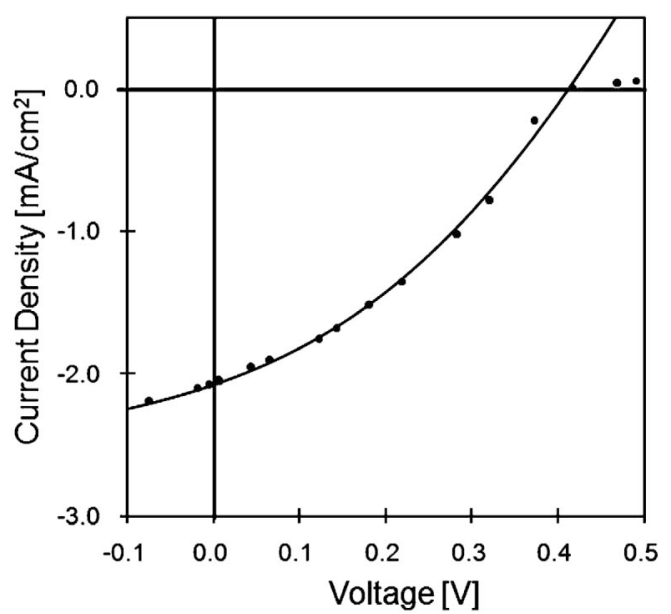

Fig. 3 The $\mathrm{I}-\mathrm{V}$ characteristics of the organic solar cell irradiated by AM $1.5 \mathrm{G}$.

に作製した有機薄膜太陽電池の断面図を示す。

作製した有機薄膜太陽電池の電流-電圧特性は AM1.5 の エアマスフィルターを備えたソーラーシュミュレータによ り，大気中で測定した.

\section{3. 結果及び考察}

Fig. 3 に作製した有機薄膜太陽電池の電流-電圧特性を示 す. 開放電圧 $(\mathrm{Voc})$ は $0.41 \mathrm{~V}$, 短絡電流密度 $(\mathrm{Jsc})$ は2.07 $\mathrm{mA} / \mathrm{cm}^{2}$, 曲線因子（Fill Factor）は 0.34 , 電力変換効率 ( $\mathrm{PCE}: \eta)$ は $0.29 \%$ となった。理論上の開放電圧は P3HT の最高被占軌道 (Highest Occupied Molecular Orbital) と PCBM の最低空軌道 (Lowest Unoccupied Molecular Orbital) から，

約 $1 \mathrm{~V}$ 程度となるのに対し, 今回得られた值はその半分程 度となっている。また短絡電流密度（Jsc），曲線因子（Fill Factor）の值も低いことから, 直列抵抗, シャント抵抗の増 大に原因する可能性が高い.さらに, クロロホルムとクロロ ベンゼンの混合溶液で, P3HT/PCBM（wt\%比 $1: 0.8 ）$ 混 合溶液を作製したため, クロロホルムの蒸発が早く, クロロ ベンゼン残量では, P3HT/PCBM バルクヘテロジャンクシ ョン層の Interpenetrating network 形成が不十分であったた めと考えられる，また，大気下で製膜を行ったため，酸化劣 化の影響を受けている可能性も示唆される. そのうえ, 現段 階では, 熱処理が行われていない。これらが作製した有機太
陽電池の低い性能に密接に関連していると考えられる．著者 らは, スピンコート法で製膜した $1 \mathrm{~cm}^{2}$ の大面積有機太陽電 池で $1.4 \%$ の電力変換効率を得ている. この面積は通常報告 されている面積の 4 倍である. 面積増大に伴い変換効率低 下を考慮すると，スピンコート法で作製した太陽電池が高い 変換効率を有することを示す. 一方, ペイント法を用いた有 機薄膜太陽電池では，0.29\%の低い変換効率を示した．これ は, 上述したように, 活性層を大気中で作製したこと, 熱処 理しなかったこと, 溶液の蒸発速度に密接に関係していると 考えら机る。

\section{4. まと め}

今回用いた作製法では, 容易に大面積化できるペイント法 を用いた有機薄膜太陽電池の作製に成功した。しかしなが ら, 本研究室において, スピンコート法で作製した有機太陽 電池の電力変換効率 $1.4 \%$ と比べ, $0.29 \%$ の低い性能を示し た.これは, 大気の影響, 有機溶媒の蒸発速度. 熱処理に原 因していると考えられる.ペイント法で高効率有機太陽電池 を得るには, 窒素雾囲気中での活性層の作製, 有機溶媒の蒸 発速度制御，熱処理を施すことが重要である.さらに，プリ ント製膜装置を製作し, 窒素雾囲気化で自動的に製膜を行え るようにする必要がある.

\section{謝辞}

本研究の一部は, 文部科学省学術フロンティア推進事業 （継続）「21世紀を支えるための材料の開発一環境，エネル ギー, 情報に資する材料開発のための基礎研究に基づく新規 デバイスの開発と実用化一」(平成19-21年度) の支援を受 けて行われたものである.

\section{[文献〕}

1) F. Padinger, R. S. Rittberger and N. S. Saricifti: Adv. Funct. Mater, 13 (2003) 85.

2) M. R-Reyes, K. Kim and D. L. Carroll: Appl. Phys. Lett., 87 (2005) 083506.

3) W. Ma, C. Yang, X. Gong, K. Lee and A. J. Heeger: Adv. Funct. Mater., 15 (2005) 1617.

4) J. Xue, B. P. Rand, S. Uchida and S. R. Forrest: Adv. Mater., 17 (2005) 66.

5) C. W. Tang: Appl. Phys. Lett., 48 (1986) 183.

6) S. Kim, S. Na, J. Jo, G. Tae and D. Kim: Adv. Mater., 19 (2007) 4410. 